\title{
Defects in mRNA 3'-end formation, transcription initiation, and mRNA transport associated with the yeast mutation prp20: possible coupling of mRNA processing and chromatin structure
}

\author{
Wayne Forrester, Francoise Stutz, ${ }^{1}$ Michael Rosbash, ${ }^{1}$ and Marvin Wickens \\ Department of Biochemistry, College of Agricultural and Life Sciences, Madison, Wisconsin 53706 USA
}

\begin{abstract}
A temperature-sensitive lethal mutation in Saccharomyces cerevisiae, prp20-1, causes defects in several different steps in mRNA metabolism, including mRNA $3^{\prime}$-end formation, transcription initiation, and mRNA transport. Previous work has demonstrated that prp20 mutants are defective in actin pre-mRNA splicing. PRP20 is related, both in structure and function, to the RCC1 gene of mammals and the PIM1 gene of Schizosaccharomyces pombe, both of which appear to regulate entry into mitosis and chromosome condensation. In this report we demonstrate that, after a shift of prp20 mutants to the restrictive temperature, transcripts of several genes (CUP1, CYH2, and GAL10) are produced that extend $1-10 \mathrm{~kb}$ beyond their normal polyadenylation sites. The failure in 3'-end formation occurs within 1-2 $\mathrm{min}$ of the temperature shift. Transcription initiation also is disrupted, in that initiation sites upstream of the normal cap site are used. mRNA transport from nucleus to cytoplasm also is perturbed: In situ hybridization using an oligo(dT) probe demonstrates accumulation of poly(A) in the nucleus, consistent with the accumulation of longer bulk poly(A) (up to $\sim 90-100$ nucleotides) and with a failure to transport newly synthesized RNA to the cytoplasm. We demonstrate that prp20 and rna1 mutants are very similar, if not identical, with respect to each of these biochemical phenotypes. In light of the putative role of PRP20 in mitotic control, our results suggest a common step in that process and multiple steps in mRNA synthesis and maturation. We speculate that the perturbations in mRNA processing are the result of effects on the chromatin-nascent RNP-transcription complex or misregulation of a cell cycle component that modifies multiple mRNA-processing activities.
\end{abstract}

[Key Words: mRNA processing; RCC1; PIM1; RNA1; polyadenylation; nuclear structure; chromatin]

Received May 20, 1992; revised version accepted July 27, 1992.

mRNAs formed in eukaryotic cells are subject to many post-transcriptional processing steps, any of which can regulate the quantity or type of mRNA produced. These steps include capping, splicing, 3 '-end cleavage, poly|A| addition, transport from nucleus to cytoplasm, poly(A) removal, and destruction of the mRNA. Their biochemical mechanisms appear to be similar in yeast and in mammals in those cases in which it has been examined (e.g., see Green 1991; Guthrie 1991). Here, we focus on post-transcriptional processing in Saccharomyces cerevisiae, concentrating on the role of the PRP20 gene product in mRNA 3 '-end formation and transport.

${ }^{1}$ Howard Hughes Medical Institute and Department of Biology, Brandeis University, Waltham, Massachusetts 02254 USA.
The mechanisms of mRNA 3 '-end formation in yeast and mammals are similar, but distinct. In both yeast and mammals, formation of mRNA 3 ' termini involves endonucleolytic cleavage of an extended primary transcript. This is followed by the post-transcriptional addition of a poly(A) tract, containing 60-100 nucleotides in yeast (Groner et al. 1974) and 250-300 nucleotides in mammals (for review, see Wickens 1990). The enzyme that adds the poly(A) tail, poly(A) polymerase, is very similar in sequence in yeast and mammals (Lingner et al. 1991; Raabe et al. 1991).

Biochemical analysis of mutations that disrupt mRNA processing in yeast has provided invaluable insight into the mechanism of RNA splicing. Some 20 genes (termed $P R P$, for pre-mRNA processing) have been identified that are likely to be essential for this one processing step. For 
3 '-end formation, however, genetic studies thus far have revealed only a single gene that is essential (Lingner et al. 1991). This gene encodes the poly(A) polymerase.

Mutations in two other yeast genes affect multiple post-transcriptional processing events, including mRNA $3^{\prime}$-end formation. A mutation in the PRP20 gene (also called SRM1) has been reported to cause accumulation of longer mRNA species, presumably by a failure to terminate or process $3^{\prime}$ ends (Aebi et al. 1990). This mutation also affects actin-intron splicing (Vijayraghavan et al. 1989), and nuclear morphology (Aebi et al. 1990) and suppresses the mating defect in a strain lacking matingfactor receptor (Clark and Sprague 1989). Similarly, mutations in the yeast RNA1 gene not only disrupt mRNA 3 '-end formation but also stable RNA production (Hutchison et al. 1969), tRNA splicing (Hopper et al. 1978; Knapp et al. 1978), and rRNA processing (Hopper et al. 1978) and may affect mRNA transport from the nucleus as well (Hutchison et al. 1969; Shiokawa and Pogo 1974; Piper and Aamand 1989). It is not clear which, if any, of the array of phenotypes associated with the prp 20 and ma1 mutations correspond to the primary sites of action of the proteins.

PRP20 is a member of a gene family that includes Schizosaccharomyces pombe PIM1, mammalian RCC1, and related genes in Xenopus and Drosophila (Ohtsubo et al. 1987; Aebi et al. 1990; Nishitani et al. 1990; Frasch 1991; Matsumoto and Beach 1991). These genes are not only similar in structure but in function as well. By genetic criteria, mammalian $R C C 1$ and S. pombe PIM1 are required for control of chromosome condensation: Lossof-function mutations in these genes cause interphase chromosomes to undergo mitotic condensation prematurely (Ohtsubo et al. 1987; Matsumoto and Beach 1991). In $S$. cerevisiae, prp20 mutants display altered nuclear morphology, consistent with a defect in chromatin structure (Aebi et al. 1990). The chromosome condensation defect may be caused by an increased $C D C 2$ activity and reflect premature entry into mitosis (Matsumoto and Beach 1991). Because the mammalian $R C C 1$ gene and the yeast $P R P 20$ gene complement one another, they are very likely to have overlapping functions in vivo (Clark et al. 1991; Fleischmann et al. 1991; Ohtsubo et al. 1991).

Although the biochemical activities of these proteins in vivo has not been demonstrated, the RCC1 protein has been shown in vitro to bind to chromatin and DNA (Ohtsubo et al. 1989) and to stimulate the GDP-GTP exchange activity of the ras-like nuclear protein $R A N$ (Bischoff and Ponstingl 1991). Like PRP20 protein, the RCC1 protein is located in the nucleus (Ohstubo et al. 1989; Fleischmann et al. 1991).

Here, we characterize in more detail the defects in 3 '-end formation and poly(A) metabolism in prp20 mutant strains, comparing them to those observed in rna1 mutants. We show that prp20 mutants exhibit defects in 3 '-end cleavage on several different mRNAs, failing to process RNAs at their normal polyadenylation sites. In addition, prp20 mutants initiate transcription at abnormal sites. By in situ hybridization, we demonstrate that the prp20 mutation blocks transport of polyadenylated RNA from nucleus to cytoplasm. In all of these biochemical phenotypes, prp20 and rna1 mutants are very similar, if not identical. We discuss several possible interpretations of these data in light of the presumed role of PRP2O in mitotic regulation, including the possibility that the collection of transcriptional and post-transcriptional phenotypes reflect a defect in the coupling of chromatin structure to mRNA processing.

\section{Results}

Inactivation of prp20 causes a decrease

in the level of specific mRNAs, and an accumulation of higher molecular weight transcripts

To analyze mRNA production in prp20 mutants, we prepared total RNA from cells that had been grown continuously at $23^{\circ} \mathrm{C}$, or had been shifted from $23^{\circ} \mathrm{C}$ to $37^{\circ} \mathrm{C}$ for $30 \mathrm{~min}$ (strains are described in Materials and methods and in Table 1). RNAs were separated by agarose-formaldehyde gel electrophoresis, transferred to nylon filters, and hybridized to gene-specific probes. For comparison, we analyzed wild-type and ma1 strains in parallel. $\mathrm{Be}$ low, we discuss our results with three mRNAs-CUP1, $C Y H 2$, and GAL1O.

CUP1 RNAs CUP1 mRNA, which encodes a yeast copper metallothionein, is 520 nucleotides long and does not contain introns (Butt et al. 1984; Karin et al. 1984). Two differences are conspicuous between CUP1 RNAs from shifted and unshifted prp20 cultures (Fig. 1A, lanes $3,4)$. First, the amount of mature CUP1 mRNA decreases after the shift. Second, much longer transcripts (indicated with arrows in Fig. 1A) accumulate after the shift. These transcripts are $\sim 1-10 \mathrm{~kb}$ longer than mature CUP1 mRNA. Although the decrease in the amount of mRNA could be caused by either a decrease in synthesis or an increase in turnover, the concomitant accumulation of much longer transcripts strongly suggests that mRNA formation is defective. RNAs from an rna1 mutant strain are very similar to those from prp20 (lanes $1,2)$.

We believe that both phenotypes-loss of maturesized mRNA and accumulation of much longer speciesare the result of the mutation in $P R P 20$, for two reasons. First, neither phenotype is observed in a wild-type strain (lanes 5,6). Second, we have analyzed five complete tetrads derived from a cross between a prp20 strain and a wild-type strain by Northern blotting and observe that temperature sensitivity and both Northern blot phenotypes cosegregate in all cases (data not shown).

CYH2 RNAs Mature CYH2 mRNA, which encodes ribosomal protein L29, is 620 nucleotides long and contains a single intron (Kaufer et al. 1983). CYH2 RNAs detected after a shift of the prp20 strain exhibit the same defects as seen with CUP1 (Fig. 1B, lanes 3,4). Specifically, the amount of mature $C Y H 2$ mRNA decreases after the shift and much longer transcripts accumulate (in- 
Table 1. S. cerevisiae strains

\begin{tabular}{|c|c|c|}
\hline Strain & Genotype & Reference \\
\hline A364A & MATa ade1 ade2 ura1 tyr1 his7 lys2 gal1 & Hartwell (1967) \\
\hline R14 & MATa leu2-3 & Winey and Culbertson (1988) \\
\hline R15 & $M A T \alpha$ leu2-3 & Winey and Culbertson (1988) \\
\hline M14 & MATa ura3-52 & M. Culbertson \\
\hline F9-1d & MATа prp20-1 ura3-52 & Fleischmann et al. (1991) \\
\hline F63-7d & MATa prp20-1 ura3-52 & this work \\
\hline 1364 & MATa ma1-1 & M. Culbertson \\
\hline F61-6b & MATa rna1-1 ura3-52 & this work \\
\hline F64-3b & MAT $\alpha$ rna1-1 ura3-52 & this work \\
\hline Y260 & МАТа rpb1-1 ura3-52 & Nonet et al. (1987) \\
\hline Y262 & MATa rpb1-1 his4-539 ura3-52 & Nonet et al. (1987) \\
\hline F66-10d & MATa rna1-1 rpb1-1 & this work \\
\hline F67-2b & MAT $\alpha$ prp20-1 rpb1-1 & this work \\
\hline RL92 & MATa prp2 leu2-3 leu2-112 ura3-52 & Vijayraghavan et al. (1989) \\
\hline RL144 & MATa prp4 leu2-3 leu2-112 lys2 tyr1 ura3-52 & Vijayraghavan et al. (1989) \\
\hline RL173 & MATa prp5 ade his7 leu2 lys2 & Vijayraghavan et al. (1989) \\
\hline
\end{tabular}

dicated with arrows). CYH2 RNAs from the rna1 mutant yield a very similar pattern of higher molecular weight RNAs (lanes 5,6 ). Our preliminary results suggest that these extended $\mathrm{CYH} 2$ RNAs are not retained on oligo(dT)-cellulose and so presumably lack poly(A), in contrast to extended transcripts produced from several other genes (St. John and Davis 1981; Aebi et al. 1990). The amount of mature CYH2 mRNA is lower in prp20 than in rna1 (cf. lane 4 with lane 6). After a temperature shift of either mutant, the mature mRNA that remains is slightly shorter. A longer transcript seen in unshifted cultures disappears. In addition, the amount of unspliced precursor decreases dramatically. This may reflect a decrease in the production of CYH2 RNAs or accelerated degradation of both the precursor and the mRNA.

The phenotypes of prp20 and rna1 do not merely result from a splicing defect because they are not observed in three mutant strains that are defective in pre-mRNA splicing, prp2, prp4, and prp5 (Fig. 1B, lanes 7-12). RNA prepared from wild-type cultures also changes very little, suggesting that the lesions in prp20 and rna1 are responsible for the processing defects (lanes 1,2 ). This conclusion is confirmed by meiotic segregation of the phenotypes: In five complete tetrads derived from a cross of prp20 with a wild-type strain, the accumulation of much longer RNAs and the production of slightly shorter, mature-sized mRNA cosegregate, yielding two defective and two wild-type spores in all cases (Fig. 1C). Identical results have been obtained with the rna1 mutant (not shown).

GAL10 RNAs GAL10 mRNA, which encodes an enzyme required for utilization of galactose, is 2250 nucleotides long and contains no introns (St. John and Davis 1981). As with CUP1 and CYH2, the amount of mature mRNA decreases after a shift and a longer transcript appears (Fig. 1D, arrow). prp20 and rna1 affect the pattern of GAL10 RNAs similarly.

Summary We conclude that prp20 and rna1 display very similar biochemical phenotypes as assessed by Northern blotting. Defects are observed with three different mRNAs, suggesting that these abnormalities may be of general significance. Decreases in length and amount of mature mRNA and pre-mRNA and even the detailed patterns of much longer transcripts are very similar, if not identical, in prp20 and rna1 mutants. These results suggest that the two mutations may affect the same process.

\section{Both transcription initiation and $3^{\prime}$-end formation are defective}

We determined whether the longer CUP1 transcripts seen in the mutants were extended at the $5^{\prime}$ or $3^{\prime}$ ends. The $5^{\prime}$ ends of CUP1 RNAs were mapped by primer extension (diagram in Fig. 2A). The resulting extension products were analyzed by gel electrophoresis. A prominent product of 240 nucleotides and two less abundant products of 249 and 440 nucleotides were detected in wild-type and unshifted mutant cells (Fig. 2A, lanes $1,2,3,5)$. The 240- and 249-nucleotide products are consistent with previously mapped $5^{\prime}$ termini (Butt et al. 1984; Karin et al. 1984). New products of 280 and 450 nucleotides were produced in prp20 cells shifted to $37^{\circ} \mathrm{C}$ (lanes 5,6), indicating that CUP1 transcripts have altered $5^{\prime}$ termini. The same defect was observed in rna1 cells (lanes 3, 4).

The 3' ends of CUP1 transcripts were mapped by incubating RNA isolated from mutant cells with a radiolabeled RNA complementary to a region spanning the polyadenylation site of wild-type CUP1 message. The RNA was then treated with single-strand-specific ribonucleases, and the protected fragments (see diagram in Fig. 2B) were analyzed by gel electrophoresis. RNAs between 105 and 120 nucleotides long were protected by RNA from wild-type and unshifted mutant cells (Fig 2B, lanes $1,2,3,5)$. Thus, the $3^{\prime}$ termini of CUP1 mRNAs lie primarily between 189 and 204 nucleotides downstream 
A

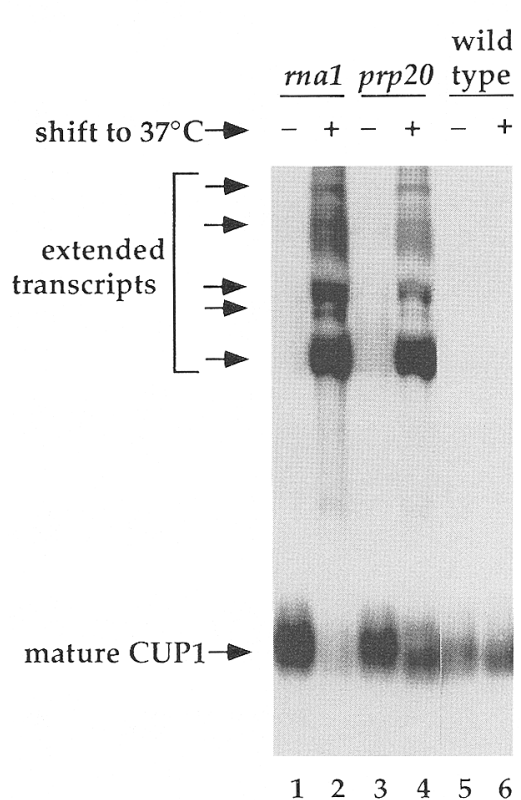

B

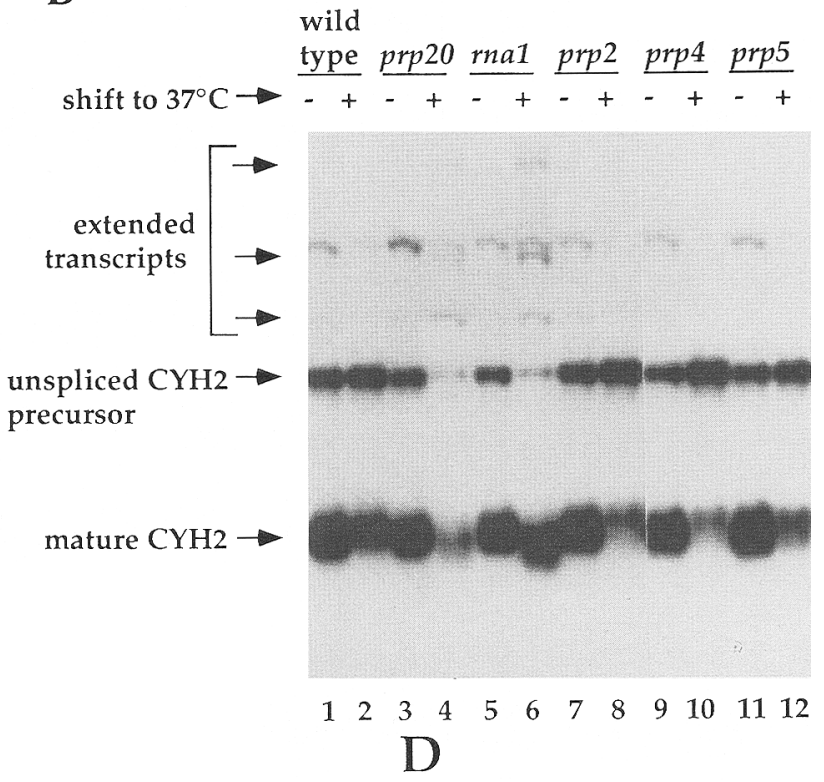

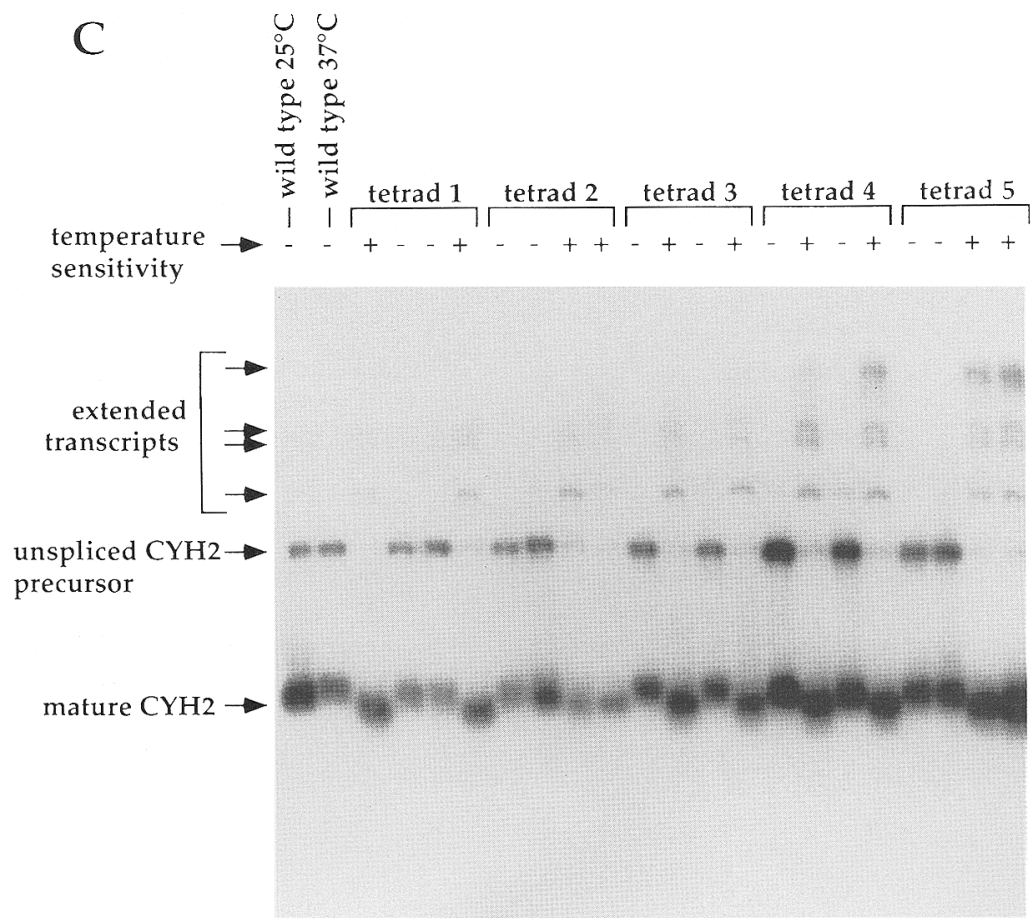

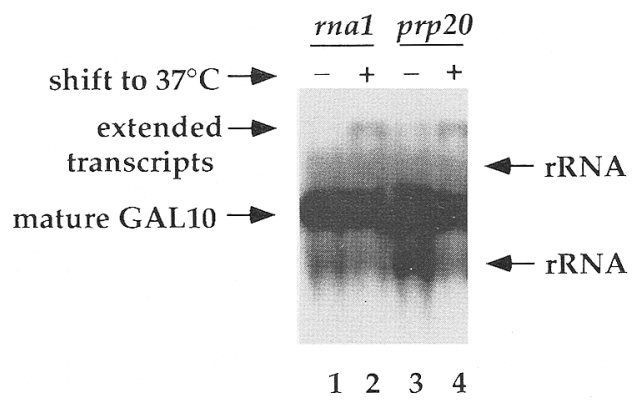

Figure 1. Inactivation of prp20 or rna1 causes a decrease in the level of specific mRNAs, and an accumulation of higher molecular weight transcripts. RNA was extracted from mutant or wildtype cultures that had been grown continuously at $25^{\circ} \mathrm{C}$ (odd-numbered lanes) or had been shifted to $37^{\circ} \mathrm{C}$ for $30 \mathrm{~min}$ (even-numbered lanes), as indicated above each lane. RNA was analyzed by Northern blotting using hybridization probes specific for CUP1 $(A), C Y H 2(B, C)$ or $G A L 10(D)$. The positions of novel high-molecular-weight species are indicated with arrows and designated $3^{\prime}$ extended, in light of later observations. (A) CUP1 transcripts. (Lanes 1,2) RNA from ma1 (F64-3b) cells; (lanes 3,4) RNA from prp20 (F63-7d) cells; (lanes 5,6) RNA from wild-type (R14) cells. (B) CYH2 transcripts. (Lanes 1,2) RNA from wild-type (A364A) cells; (lanes 3,4) RNA from prp20 (F9-1d) cells; (lanes 5,6) RNA from rna1 (1364) cells; (lanes 7,8) RNA from prp2 (RL92) cells; (lanes 9,10) RNA from prp4 (RL144) cells; (lanes 11,12) RNA from prp5 cells. (C) CYH2 transcripts: meiotic cosegregation of the various RNA-related phenotypes with one another and with temperature sensitivity. prp20(F9-1d) and wild-type (R15) cells were crossed and sporulated. The four spores of five different tetrads were dissected and grown at $25^{\circ} \mathrm{C}$. Cultures were shifted to $37^{\circ} \mathrm{C}$ for $30 \mathrm{~min}$. RNA was then prepared and analyzed by Northern blotting using a CYH2-specific probe. In each tetrad, two spores were temperature sensitive for growth, whereas two were not, as indicated above each lane. $(D)$ GAL10 transcripts. (Lanes 1,2) RNA from rna1 (F64-3b) cells; (lanes 3,4) RNA from prp20 (F63-7d) cells.

of the termination codon. RNA from prp20 after the shift protected the entire region of homology, which resulted in a band of 207 nucleotides (lane 6). The same pheno- type was observed in rna1 cells (lane 4). Therefore, the RNAs produced by the mutants after the shift extend past the normal poly(A) site by at least 100 nucleotides. 
B
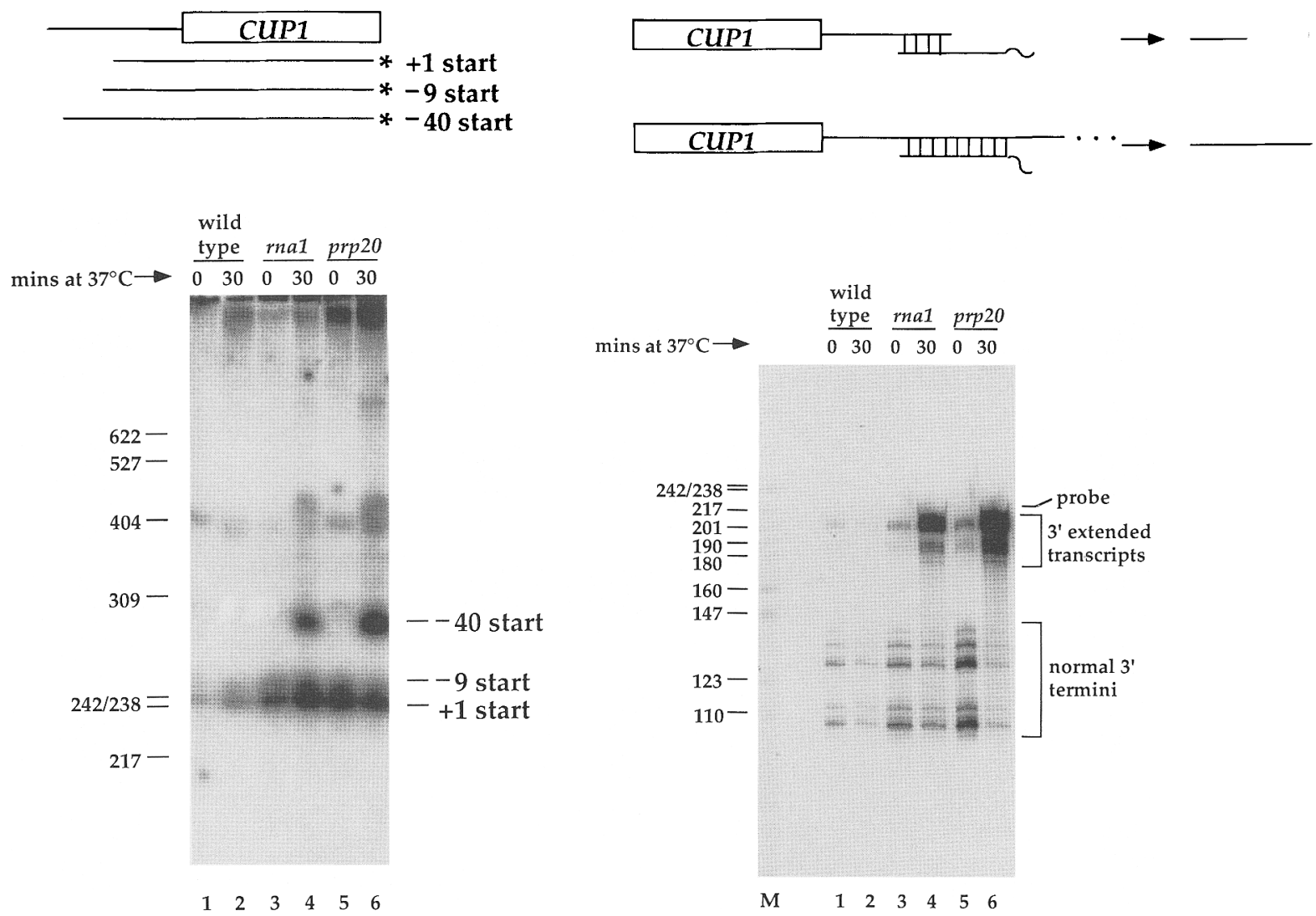

Figure 2. Both transcription initiation and $3^{\prime}$-end formation are defective. $(A) 5^{\prime}$ Termini of CUP1 transcripts. $5^{\prime}$ Termini were determined by primer extension, using a $5^{\prime}$-end-labeled primer that anneals to the position indicated by an asterisk $\left({ }^{*}\right)$. The primer was hybridized to total RNA and extended using reverse transcriptase. The lengths and positions of the major primer extension products are shown. The box indicates the $5^{\prime}$ boundary of the CUP1 open reading frame. Cultures were grown continuously at $25^{\circ} \mathrm{C}$ (oddnumbered lanes) or shifted to $37^{\circ} \mathrm{C}$ for $30 \mathrm{~min}$ (even-numbered lanes), as indicated above each lane. Numbers to the left of the autoradiograph indicate the positions of molecular weight markers (MspI-cleaved pBR322 fragments). (Lanes 1,2) RNA from wild-type (R14) cells; (lanes 3,4) RNA from rna1 (F64-3b) cells; (lanes 5,6) RNA from prp20 (F63-7d) cells. (B) 3' Termini of CUP1 RNAs. 3' Termini were determined by RNase protection, using a uniformly labeled RNA complementary to the region spanning the polyadenylation site of CUP1 RNAs in wild-type cells (positions +325 to +532 ). The diagrams illustrate the RNase-resistant products formed with wild-type mRNA (top; lengths of $\sim 120$ nucleotides) and with transcripts that extend past the normal polyadenylation site (bottom; $\sim 200$ nucleotides). $\sim$ indicates nonhomologous sequences in the polylinker region of the probe. The box indicates the $3^{\prime}$ boundary of the CUP1 ORF. Cultures were grown continuously at $25^{\circ} \mathrm{C}$ (odd-numbered lanes) or shifted to $37^{\circ} \mathrm{C}$ for 30 min (evennumbered lanes|, as indicated above each lane. Numbers to the left of the autoradioagraph indicate the positions of molecular weight markers (MspI-cleaved pBR322 fragments). (Lanes 1,2) RNA from wild-type (R14) cells; (lanes 3,4) RNA from ma1 (F64-3b) cells; (lanes $5,6)$ RNA from prp20 (F63-7d) cells.

Presumably, they extend $\geqslant 1 \mathrm{~kb}$ downstream of the normal $3^{\prime}$ end, given the lengths observed by Northern blotting (Fig. 1).

To determine whether the $5^{\prime}$ and $3^{\prime}$ termini of $C Y H 2$ mRNAs are altered in prp20 and rna1 strains, we performed RNase protection experiments analogous to those in Figure 2 (data not shown). After a temperature shift of prp2O and ma1 strains, CYH2 $5^{\prime}$ termini were detected more than 160 nucleotides upstream of the normal cap site, whereas $3^{\prime}$ termini were detected $>190$ nucleotides downstream of the normal polyadenylation site. These novel $5^{\prime}$ and $3^{\prime}$ ends were not observed in wild-type strains.
To summarize, transcripts produced after shifting either prp20 or rna1 mutants to the restrictive temperature display altered $5^{\prime}$ and $3^{\prime}$ termini. We conclude that mutations in either of these two genes disrupt both transcription initiation and mRNA 3 '-end formation.

\section{Extended transcripts are produced very soon after a temperature shift}

To gain insight into whether prp20 affects 3 '-end formation directly, we determined how soon after a temperature shift $3^{\prime}$-end formation went awry. Cells were grown at $23^{\circ} \mathrm{C}$ and shifted for $0,1.3,2.5,7$, or $10 \mathrm{~min}$ to $37^{\circ} \mathrm{C}$. 
Cells were poured over crushed ice and collected by centrifugation, and RNA was isolated immediately. Even after only $1.3 \mathrm{~min}$, extended CUP1 RNAs were detected in prp20 (Fig. 3, lane 7). Similar amounts of longer transcripts were detected in rnal even at the shortest time points. The amount of extended transcript increased until 2.5 to $7 \mathrm{~min}$, when it reached a maximum.

The very rapid appearance of long transcripts after a shift argues strongly against models in which the observed effects require synthesis of a new factor. It is consistent with a cotranscriptional defect in mRNA 3 '-end formation.

Shortening of mature-sized RNAs is due to loss of $\operatorname{poly}(A)$ from pre-existing $m R N A s$

Mature-sized CYH2 RNA is 20-30 nucleotides shorter in prp20 and rna1 cells following a shift to the restrictive temperature (Fig. 1B, lanes 4,6). A similar decrease in length is seen with CYC1 and ribosomal protein L32, L4, and S7 mRNAs (not shown). To test whether the decrease in length was due to loss of poly(A), total RNA from wild-type, prp20, and rna1 cells was incubated with an anti-CYH2 oligonucleotide and RNase $\mathrm{H}$, with or without oligo(dT) (diagram in Fig. 4). RNase $\mathrm{H}$ cleaves the CYH2 message to produce a 198-nucleotide $3^{\prime}$ fragment as a result of the annealing of the anti-CYH2 oligonucleotide and removes poly(A) only in the presence of oligo(dT). The size of the resulting $3^{\prime}$ fragments of the mRNA were determined by Northern blotting.

The poly(A) tail of CYH2 mRNAs in wild-type, prp20, and rna1 cells, grown at $23^{\circ} \mathrm{C}$ is $\sim 20-30$ nucleotides (Fig. 4 , lanes $1,2,5,6,9,10)$. The $C Y H 2$ poly(A) tail is very short or missing after a shift of prp20 and rna1 cells (Fig. 4, lanes $7,8,11,12$ ). The amount and length of mature $C Y H 2$ mRNA decreases progressively in both prp20 and rna1 following a shift to the restrictive temperature (data not shown).

The lack of poly(A) on CYH2 mRNA after a temperature shift could be the result of deadenylation of mRNA that was present before the shift or de novo synthesis of
poly(A)-deficient RNAs after the shift. To distinguish between these possibilities, we determined whether shortening was observed when transcription was blocked during the temperature shift. To block transcription, we generated double mutants containing $r p b 1$, a temperature-sensitive mutation in a subunit of RNA polymerase II (Nonet et al. 1987), with either prp20 or rna1. In an $r p b 1$ mutant, CYH2 mRNA decreases in abundance and length as expected from its reported half-life and deadenylation (Fig. 5, lanes 3,4; Herrick et al. 1990). The amount and length of $C Y H 2$ mRNA decreases in prp20 rpb1 and rna1 rpb1 double mutants (lanes 7-10). The amount of mRNA remaining differs between strains, most likely reflecting effects on mRNA turnover in the different backgrounds. Accumulation of the longer transcripts is also blocked in the double mutants, demonstrating that those RNAs result from transcription only after the shift.

We conclude that the poly $(\mathrm{A})^{-} \mathrm{CYH} 2 \mathrm{mRNA}$ observed after the temperature shift was produced by deadenylation of pre-existing mRNA. We presume that this reflects normal CYH2 mRNA metabolism but is particularly visible in the mutants because the formation of new, mature-sized mRNA is blocked.

\section{Bulk poly $(A)$ length distribution changes} after a temperature shift

rna1 mutants accumulate mRNA with longer poly(A) tails after a shift to the restrictive temperature (Piper and Aamand 1989|. It has been suggested that this reflects a defect in transport of mRNA from nucleus to cytoplasm, such that nuclear mRNAs, with long poly(A) tails, are not exposed to the cytoplasmic poly $(\mathrm{A})$ removal apparatus (Hutchison et al. 1969; Shiokawa and Pogo 1974; Piper and Aamand 1989).

To determine whether prp20 might also impair mRNA transport, we first measured poly(A) length in total RNA extracted from prp20 cells after a shift. Total RNA was treated with ribonuclease to degrade sequences other
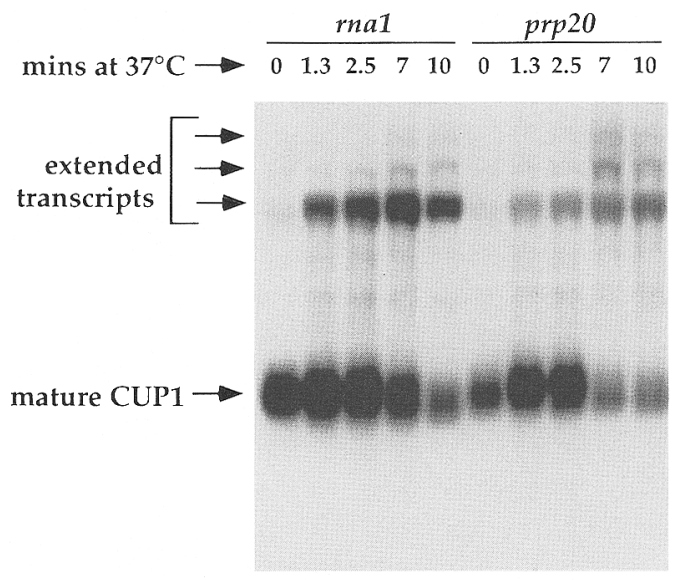

$\begin{array}{llllllllll}1 & 2 & 3 & 4 & 5 & 6 & 7 & 8 & 9 & 10\end{array}$
Figure 3. Extended transcripts are produced very soon after a temperature shift. RNA was prepared from rna 1 (F64-3b) or prp20 (F63-7d) cells that had been shifted to $37^{\circ} \mathrm{C}$ for varying lengths of time, as indicated above each lane. CUP1-specific transcripts were detected by Northern blotting using a CUP1specific probe. (Lanes 1-5) RNA from rna1 cells; (lanes 6-10) RNA from prp20 cells. 


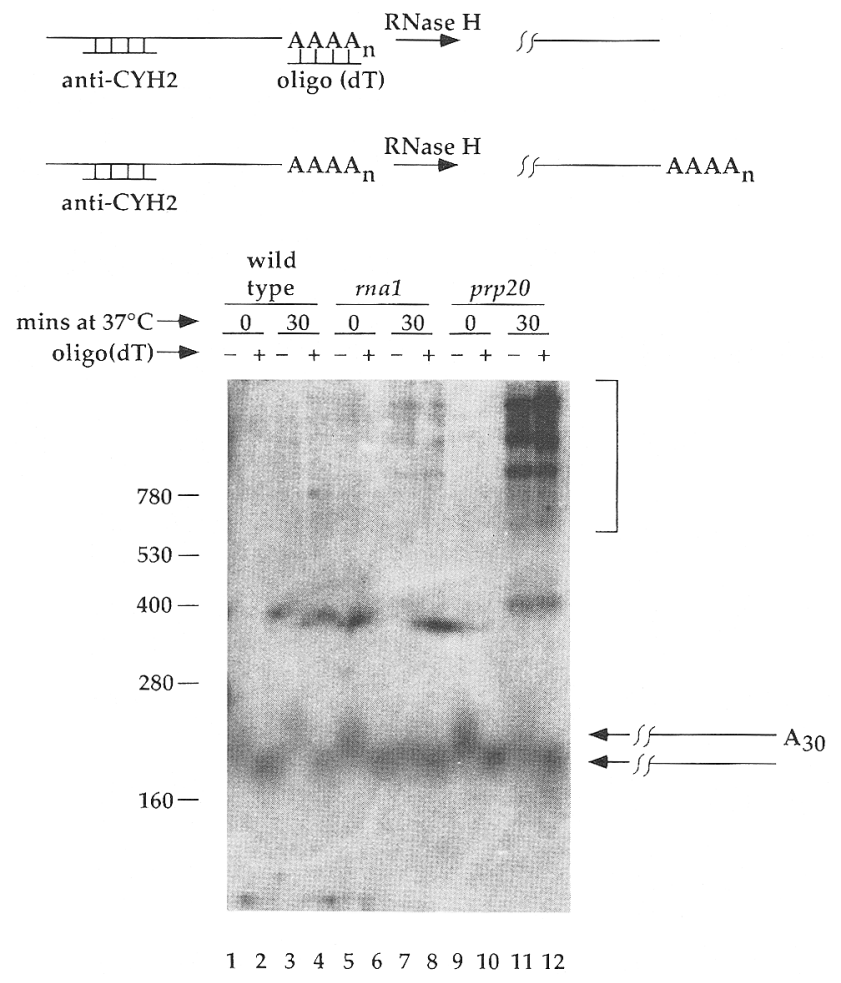

Figure 4. Shorter $C Y H 2$ RNAs after a temperature shift lack poly(A). The length of poly(A) present on CYH2 RNAs was determined using the oligonucleotide/RNase $\mathrm{H}$ protocol diagramed at top. RNAs were incubated with RNase $\mathrm{H}$ and an oligonucleotide complementary to nucleotides +837 to +861 of CYH2 mRNA, thereby generating short ( $\sim 200$ nucleotides) $3^{\prime}$ fragments of $\mathrm{CYH} 2$ mRNAs. Poly(A) tails were removed from half of each sample, using oligo(dT) and RNase H. RNAs were analyzed by Northern blotting, using a CYH2-specific probe extending from +840 to +1300 . The length of poly $(A)$ is calculated from the difference in length between samples incubated with or without oligo(dT), as indicated above each lane. The duration of the growth at $37^{\circ} \mathrm{C}$ is indicated above each lane as well. Ten micrograms of total RNA was used per lane, except in lanes $3,4,11$, and 12 , in which $20 \mu \mathrm{g}$ of RNA was used to normalize signal. (Lanes 1-4) RNA from wild-type (R14) cells; (lanes 5-8) RNA from rna1 (F64-3b) cells; (lanes 9-12) RNA from prp20 (F63-7d) cells.

than poly(A). The remaining RNA fragments were radiolabeled and analyzed by gel electrophoresis.

The distributions of poly(A) lengths in wild-type cells at $23^{\circ} \mathrm{C}$ or $37^{\circ} \mathrm{C}$ are very similar (Fig. 6 , lanes 1,2 ). The poly(A) lengths present in RNA from prp20 and rna1 cells grown at $23^{\circ} \mathrm{C}$ are comparable to wild type (lanes $3,5)$. After a shift, however, both prp20 and rna1 strains accumulate RNA with longer poly(A) tails, with peak lengths of between 60 and 90 nucleotides (lanes 4,6). The peak length is slightly shorter with prp20 than with rna1. Concomitantly, poly(A) tails of $\leqslant 60$ nucleotides decrease in abundance. The loss of shorter poly(A) tails is consistent with the deadenylation of $C Y H 2$ mRNA seen after a shift to the restrictive temperature (see Fig. 4).

These results suggest that prp20 cells may accumulate newly synthesized mRNA in the nucleus. The increase in longer poly(A) tails could reflect newly synthesized poly(A) that is protected from cytoplasmic deadenylation by retention in the nucleus, whereas the decrease in shorter poly $(\mathrm{A})$ tails could result from the deadenylation of mRNAs that were already in the cytoplasm before the temperature shift.

\section{$\operatorname{Poly}(A)$ accumulates in the nucleus in prp20 and rnal cells after a temperature shift}

To test directly whether poly $(\mathrm{A})$ accumulates in the nucleus after a temperature shift of prp20 and rna1 cells, we analyzed the distribution of bulk poly(A) by in situ hybridization. Cells were permeabilized, fixed, and hybridized to digoxigenin-labeled oligo(dT). The oligo(dT) was visualized using rhodamine-conjugated anti-digoxigenin antibody. The location of the nucleus in each cell was determined by DAPI staining.

The nuclei of prp20 or $m a 1$ cells shifted to $37^{\circ} \mathrm{C}$ for 30 min stain prominently with oligo(dT) (Fig. 7). In unshifted cultures, the staining is diffuse and cytoplasmic; nuclei are conspicuously unstained (Fig. 7). Cytoplasmic staining decreases after the shift. The nuclear staining observed at $37^{\circ} \mathrm{C}$ is somewhat less intense with prp20 than with rna1 cells. Approximately $50 \%$ of prp 20 cells show increased nuclear staining, as compared with nearly $100 \%$ with rna1.

From these data, we conclude that prp20 and ma1 result in the accumulation of poly(A) in the nucleus. We infer that like rna1, prp20 mutants are defective in mRNA transport to the cytoplasm.

\section{Discussion}

The results presented in this report indicate that a temperature-sensitive lesion in the PRP20 gene results in several defects in mRNA metabolism. First, mature mRNA levels decrease after a shift to the restrictive temperature. In addition to the three mRNAs analyzed here (Fig. 1), seven other genes yield similar results (data not shown), suggesting that this phenotype is common to many genes. Second, the formation of $3^{\prime}$ termini is defective: $3^{\prime}$ termini are formed at sites 1-10 kb downstream of the wild-type polyadenylation site of three different mRNAs. This result, reported previously for a single RNA (Aebi et al. 1990), has been extended here to include several other transcripts and has been confirmed by RNase mapping experiments. Longer transcripts also are observed with the TCM1 and $P A B$ genes (Aebi et al. 1990), but these have not been characterized biochemically. Thus, the defect in $3^{\prime}$-end formation is likely to occur on many genes in $S$. cerevisiae. Third, transcription initiation is perturbed because CUP1 and CYH2 transcripts possess novel $5^{\prime}$ termini. Fourth, transport of mRNA from the nucleus to the cytoplasm is defective, as indicated by in situ hybridization to oligo(dT). Fifth, the distribution of total poly(A) tail lengths changes after a temperature shift, with a dramatic increase in the abundance of longer lengths and a decrease in the abun- 


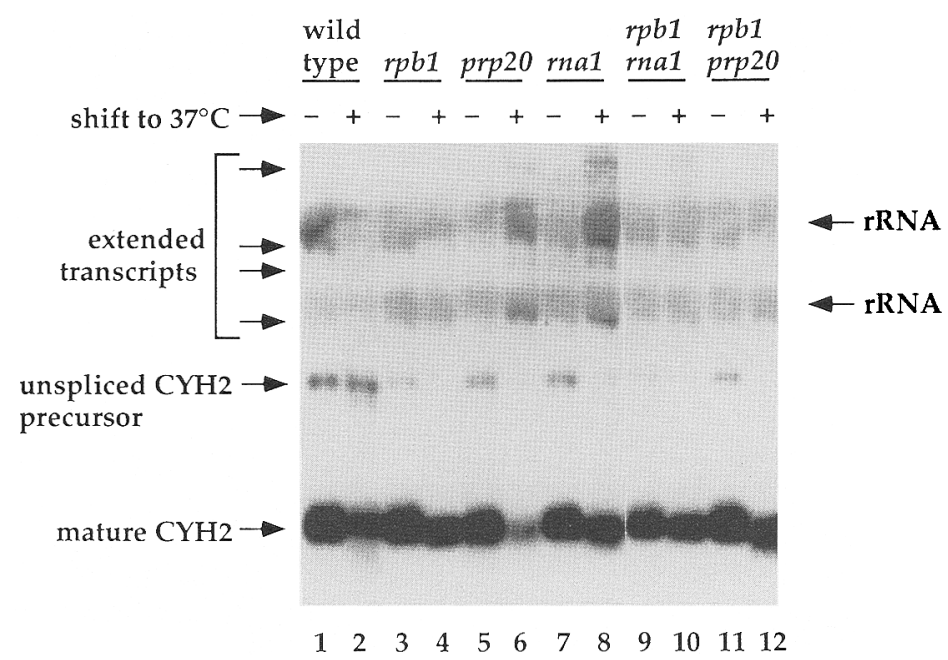

Figure 5. $C Y H 2$ mRNA without poly $(A)$ is derived from RNA produced prior to the temperature shift. RNAs were analyzed by Northern blotting, using a hybridization probe complementary to the $\mathrm{CYH} 2$ gene (see Materials and methods). RNA was prepared from cells that had been grown continuously at $25^{\circ} \mathrm{C}$ (odd-numbered lanes) or that had been shifted to $37^{\circ} \mathrm{C}$ for $30 \mathrm{~min}$ (even-numbered lanes), as indicated above each lane. (Lanes 1,2) RNA from wild-type (R14) cells; (lanes 3,4) RNA from rpb1 (Y260) cells; (lanes 5,6) RNA from prp20 (F63-7d) cells; (lanes 7,8) RNA from ma1 (F61-6b) cells; (lanes 9,10) RNA from the rpb1 ma1 double mutant (F66-10d); (lanes 11,12) RNA from the rpb1 prp20 double mutant (F67-2b). Extended transcripts are indicated by arrows. The material detected in wild-type cells near the positions of the 3 '-extended transcripts in rRNA, as indicated to the right of the autoradiograph. dance of shorter lengths. In addition to these phenotypes, prp20 also is defective in the splicing of actin pre-mRNA (Vijayraghavan et al. 1989). Splicing of CYH2 mRNA is not obviously impaired (Fig. 1B), but this could reflect accelerated degradation of the unspliced pre-mRNA, as is observed with mature CYH2 mRNA. Finally, the prp20 mutation may also impair transcription termination because it has been reported that termination in yeast occurs quite close to poly(A) addition sites (Osborne and Guarente 1989).

Some of these defects are likely to be the result of a lesion at an upstream step in mRNA synthesis or maturation. For example, a failure to transport mRNA would account for the increase in longer poly(A) lengths. The transport defect itself could be the result of a failure in 3 '-end formation. Similarly, the decrease in the amount of mature mRNA probably reflects the defects in initiation and 3'-end formation: Because mature-sized mRNA is no longer efficiently formed after the temperature shift, the decay of mRNA that was present before the shift becomes visible. This would account for the decrease in the average length of poly(A) on specific mRNAs, as well as the decreased abundance of short, cytoplasmic poly(A).

Quantitative differences between transcripts are likely to be the result of differing rates of synthesis and degradation, characteristic of those RNAs. mRNAs differ in decay rates (Herrick et al. 1990), which could explain the variable rates of decay observed after a shift. Alternatively, the supply of mature-sized mRNAs could be more severely impaired with one transcript than another. Although three genes produce novel, long transcripts extended at their $3^{\prime}$ ends, the quantity of these extended transcripts varies considerably between genes. Again, this presumably reflects differences in the intrinsic stability of these aberrant RNAs and in the rate with which each gene is transcribed to produce the aberrant RNA.

We have assayed rna1 and prp 20 mutant phenotypes in parallel and observe that the two mutations behave very similarly. Particularly striking are qualitative aspects of the data. For example, the distribution of specific initiation sites and of extended transcripts is very similar, if not identical, in the two mutants. Thus, the differences between genes are likely to be gene-specific responses to the same defect and not a consequence of either prp 20 or rna1. In some experiments, low levels of aberrant initiation and termination events are detectable even in the wild-type strain, suggesting that prp20 and rna1 enhance an intrinsic gene-specific property. prp 20 and $r n a 1$ could either increase the frequency of the rare event, or decrease the frequency of the common, wild-type event. In the particular case of $3^{\prime}$ end formation, the mutants could decrease the frequency of proper $3^{\prime}$-end cleavage from near $100 \%$ to some lower level. This change would cause a dramatic increase in the abundance of transcripts with 3' extensions and would yield a pattern of extended transcripts that varies from one gene to another.

The PRP20 protein is nuclear (Fleischmann et al. 1991), whereas the RNA1 protein is cytoplasmic (Hopper et al. 1990). Although the predominantly cytoplasmic location of RNA1 protein complicates explanations of how the rna1 allele disrupts nuclear events, a fraction of the protein could be nuclear, or RNA1 protein could be involved in some form of cytoplasmic-nuclear signaling, as proposed by Hopper et al. (1990). Although the great similarity in the phenotypes of rna1 and prp20 suggests that they might affect the same process, we observe no synthetic lethality in ma1 prp20 double mutants (not shown).

The similarities between PRP20 and the human gene, $R C C 1$, and an $S$. pombe gene, PIM1, suggest that all of the RNA-related phenoytpes of prp20 mutants may be consequences of improper regulation of the cell cycle and/or chromosome structure. PRP20 is $30 \%$ identical over a 474-amino-acid stretch with human $R C C 1$ protein and S. pombe PIM1 protein (Aebi et al. 1990; Matsumoto and Beach 1991). Each member of this family contains 7 repeats of a 60-amino-acid domain (Ohtsubo et al. 1987). Mammalian cells that are homozygous for a point mutation in $R C C 1$ undergo premature chromo- 


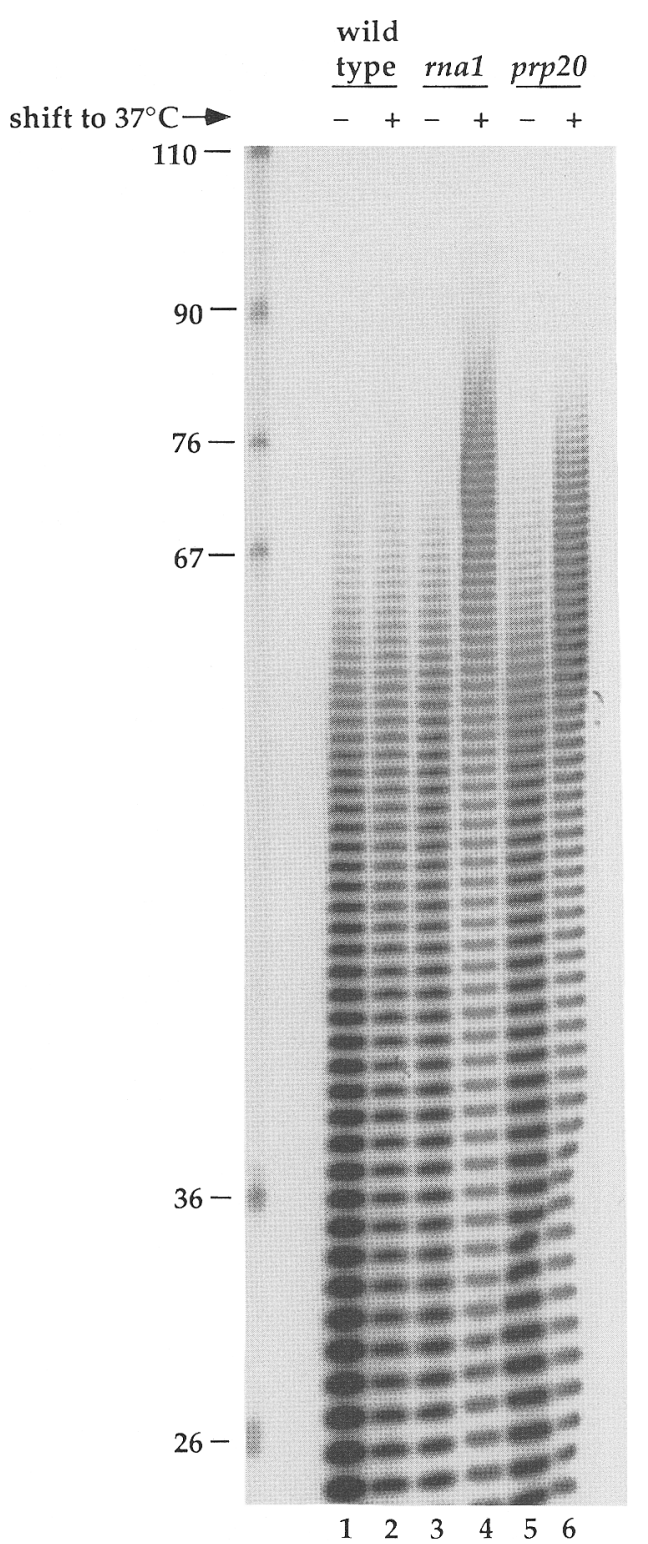

Figure 6. Bulk poly(A) length distribution changes after a temperature shift. Poly(A) length distributions were determined by digesting total RNAs to completion with RNases $\mathrm{Tl}$ and $\mathrm{A}$. The resistant oligo(A) and poly(A) segments were then $3^{\prime}$-end-labeled using RNA ligase and $\left[{ }^{32} \mathrm{P}\right] \mathrm{pCp}$. RNA was prepared from cells that had been grown continuously at $25^{\circ} \mathrm{C}$ lodd-numbered lanes) or had been shifted to $37^{\circ} \mathrm{C}$ for $30 \mathrm{~min}$ (even-numbered lanes), as indicated above each lane. The positions of DNA length markers (MspI fragments of pBR322) are indicated to the left of the autoradiograph. (Lanes 1,2) RNA from wild-type (R14) cells; (lanes 3,4) RNA from rna1 (F64-3b) cells; (lanes 5,6) RNA from prp20 (F63-7d) cells.

some condensation at the restrictive temperature (Uchida et al. 1990). Similarly, the $S$. pombe pim1 mutation was identified as a temperature-sensitive lethal lesion that caused premature chromosome condensation and mitotic spindle formation after a shift to the restrictive temperature (Matsumoto and Beach 1991). S. cerevisiae strains that lack PRP20 also display alterations in both the nucleolus and the nucleoplasm after a temperature shift, demonstrating that it too results in a perturbation of nuclear or chromosomal structure /Clark and Sprague 1989; Aebi et al. 1990). Because the mammalian $R C C 1$ gene can rescue the temperature-sensitive lethality of a prp 20 mutant strain, and the PRP20 gene can rescue $R C C 1$-defective mammalian cells (Clark et al. 1991; Fleischmann et al. 1991; Ohtsubo et al. 1991), these two genes are likely to have overlapping functions.

The defects observed in rcc1 and pim1 mutants probably arise from misregulation of entry into mitosis. For example, pim 1 mutants enter mitosis directly from $G_{1}$, in a process that requires the $C D C 2$ gene product (Matsumoto and Beach 1991). A high-copy suppressor of pim1, called SPI1, itself affects entry into mitosis and chromosome condensation (Matsumoto and Beach 1991). S. pombe SPI1 is very similar in sequence to the mammalian gene RAN (Matsumoto and Beach 1991), with which $R C C 1$ protein appears to interact biochemically (Bischoff and Ponstigl 1991). Both SPI1 and RAN are nuclear, ras-like proteins; their homolog in $S$. cerevisiae, if any, has not yet been identified.

On the basis of the putative function of the PRP2O PIM1-RCC1 gene family, we suggest two distinct models for the role of $P R P 20$ in mRNA maturation. In the first model, PRP20 participates directly in several different RNA-processing steps. The global disruptions of mRNA maturation in the mutants happen to manifest themselves as cell cycle defects. For example, in $S$. pombe, because $C D C 2$ is required for the pim1 phenotype (Matsumoto and Beach 1991), changes in the metabolism of this or another functionally related mRNA could cause premature mitosis. Consistent with this view, the RNA-processing defects of prp20 in S. cerevisiae are detected after only a few minutes (Fig. 3), whereas mitotic defects are observed only after hours with pim1 in S. pombe (Matsumoto and Beach 1991). We find this hypothesis unattractive, however, both because it requires that a single gene product participate directly in a wide diversity of RNA processing steps and that global disturbances in mRNA metabolism result in a very similar phenotype (entry into mitosis) in distantly related organisms.

A second hypothesis proposes that all of the RNArelated phenotypes of the prp20 mutation are secondary consequences of a primary defect in a single, upstream target. Chromatin-in particular, the structure of the chromatin-nascent ribonucleoprotein (RNP)-transcription complex-is a particularly attractive possibility for such a target, in light of the chromosome condensation effects described above. Our observation that sites of transcription initiation are altered in prp20 mutants is readily explained by a change in chromatin structure. This hypothesis also is consistent with the very rapid appearance of aberrant $3^{\prime}$ termini after a shift to $37^{\circ} \mathrm{C}$ (Fig. 3) and the notion that mRNA $3^{\prime}$-end cleavage occurs cotranscriptionally (Nevins and Darnell 1978; Logan et al. 1987; Connelly and Manley 1988). In this context, the splicing defect in prp20 mutants/Vijayraghavan et al. $1989)$ would imply that some aspect of spliceosome as- 
$\operatorname{rna1}, 25^{\circ} \mathrm{C}$
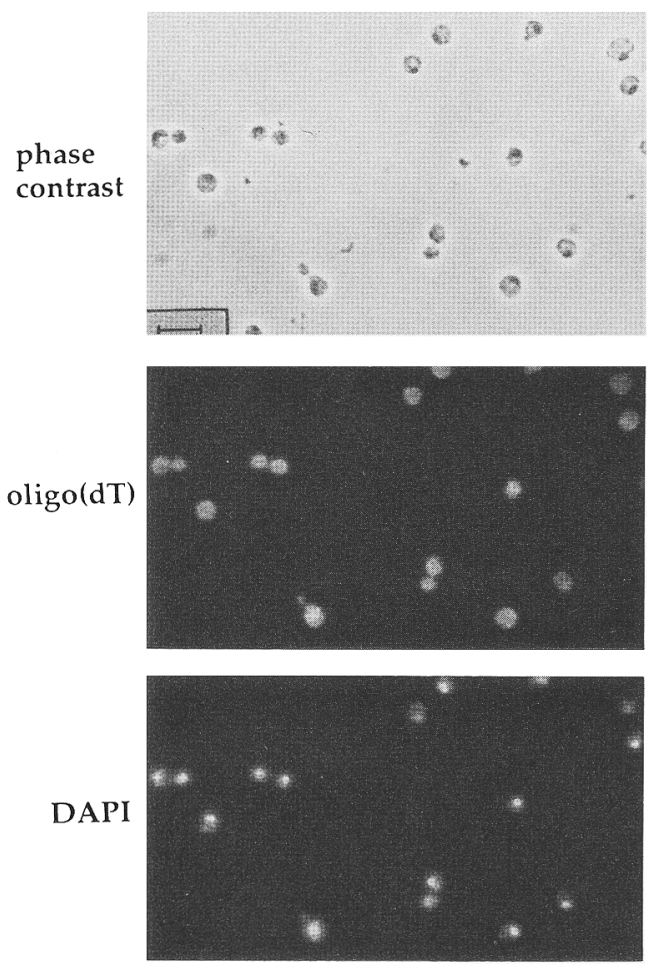

$\operatorname{ma1}, 37^{\circ} \mathrm{C}$
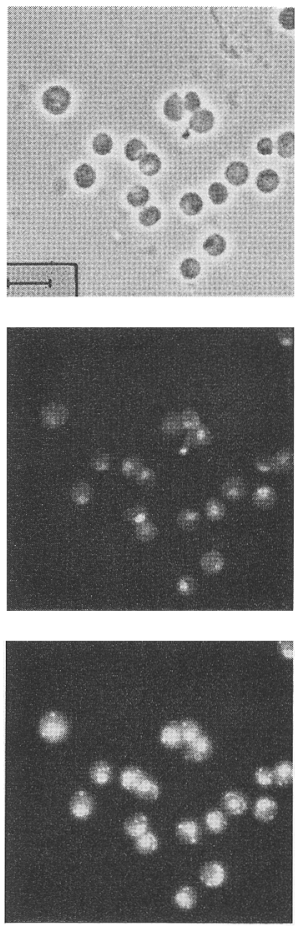

$\operatorname{prp} 20,25^{\circ} \mathrm{C}$
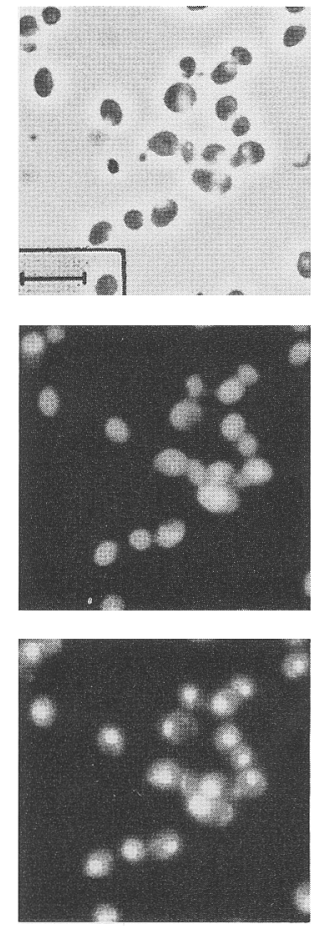

$\operatorname{prp} 20,37^{\circ} \mathrm{C}$
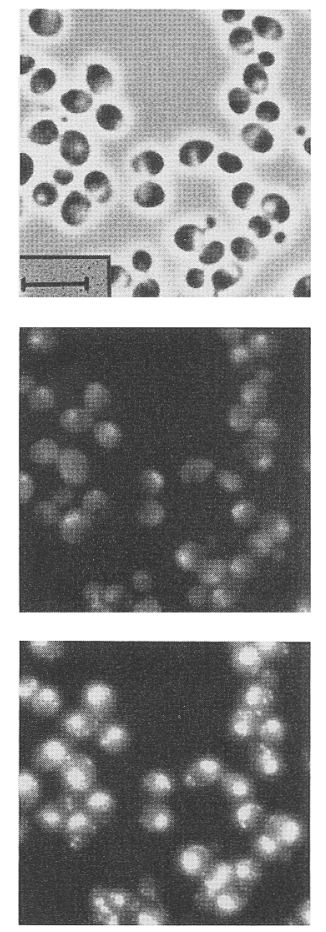

Figure 7. Poly(A) accumulates in the nucleus of prp20 and ma1 cells after a temperature shift. rna1(F64-3b) or prp20 (F63-7d) cells were grown continuously at $25^{\circ} \mathrm{C}$ (first and third columns) or were shifted to $37^{\circ} \mathrm{C}$ for $30 \mathrm{~min}$ (second and fourth columns), before fixing and staining. The three photos in each column show the same field of cells. The top row shows the cells viewed by phase-contrast microscopy (bar, $10 \mu \mathrm{m})$. The middle row shows the same cells stained with oligo(dT)-digoxigenin and probed with anti-digoxigenin antibody conjugated with rhodamine and viewed by fluorescence. The bottom row shows the cells stained with DAPI and viewed by fluorescence to identify the position of the nucleus.

sembly occurs cotranscriptionally, a notion for which there is evidence in both Drosophila (Beyer and Osheim 1988; LeMaire and Thummel 1990) and in yeast (D.J. Elliott and M. Rosbash, unpubl.). The effect of prp20 on mRNA transport from nucleus to cytoplasm might be an independent manifestation of the chromatin defect (e.g., improper cotranscriptional assembly of an RNP complex required for transport) or could be a consequence of improper 3 '-end formation (Eckner et al. 1991). 3'-End formation is not detectably perturbed in vivo in extracts derived from prp20 mutant cells (S. Butler, pers. comm.), suggesting that $P R P 20$ may act upstream of mRNA processing per se. An alternative primary defect in prp20 mutants could lie in regulation of the cell cycle. Again, this primary defect could lead to secondary defects in many different RNA-processing steps. $c d c 2$ is epistatic to pim1 (Matsumoto and Beach 1991), and RCCl mutants can affect $C D C 2$ kinase activity (Nishitani et al. 1991). Thus, the mRNA maturation defects seen in prp20 mutants could be caused by inappropriate regulation of CDC28 or another regulator of the cell cycle. For example, loss of prp20 function could activate the CDC28 kinase. In turn, this misregulated activity could then modify multiple targets involved in mRNA 3 '-end formation, transcription initiation, splicing, and transport.
These targets for modification might be recognized in the normal transition from $G_{2}$ to $M$, or they could be modified only in the aberrant situation in which cells actively transcribing and processing RNAs enter mitosis directly from $G_{1}$ or S. Finally, we note that primary defects in processes other than chromatin structure or entry into mitosis, on which we have focused here, are also consistent with the data.

Our results raise the possibility that mRNA processing and chromatin structure or mitotic control are coupled but do not establish the nature of the connection. To elucidate the primary function of PRP20, it will be necessary to identify the components with which it interacts in vivo. These components could participate directly in mitotic control, chromatin condensation, or mRNA processing and may include homologs of $S$. pombe SPI1 and human RAN. It will be necessary to establish an in vitro system in which mRNA processing is sensitive to $P R P 20$ protein. To this end, cell-free systems in which mRNA processing is coupled to transcription of chromatin may be essential. Finally, an examination of mRNA processing in cdc28 mutants, and of mitotic regulation in rna1 mutants, may help illuminate whether the defects in mRNA processing are primary or secondary consequences of improper cell cycle control. 


\section{Materials and methods}

Yeast strains

Strains are listed in Table 1. Lowercase italics (e.g., prp20) are used to designate mutant genes; uppercase italics (e.g., PRP20) indicate wild-type genes. For clarity, we have used this same convention regardless of species. Strain 1364 was crossed sequentially with strain M14 and R15 to generate F61-6b and F64-3b. F9-1d was crossed with R15 to generate F63-7d. F66-10d was generated by crossing F62-9c with Y260. F67-2b was generated by crossing F63-7d with Y262. The spores analyzed (Fig. $1 \mathrm{C}$ and data not shown/ were from crosses of prp20 (F9-1d) with wild-type (R15) (five complete tetrads) and of $r n a 1$ (F61-6b) with wild-type (R14) (eight complete tetrads). Cultures were grown and RNA was analyzed as described below. All crosses were performed using standard yeast techniques. Cultures were grown in YPD medium or in SC with $2 \%$ galactose in place of dextrose (Sherman 1991) to induce expression of the galactose utilization genes.

\section{Plasmids}

Plasmid pWF1 was constructed by cloning an Xbal-KpnI genomic restriction fragment extending from position -228 to +475 (numbers are relative to the A of the AUG) of the CUP1 gene into pGEM3Z (Promega). Plasmid pWF6 contains a HincIIEcoRI fragment extending from position -400 to +860 of the CYH2 gene inserted into pGEM3Z. Plasmid pWF38 was generated by ligating an EcoRI-SalI fragment encompassing much of the GAL10 open reading frame [from plasmid pNN76/St. John and Davis 1981), provided by M. Johnston| into pGEM3Z. Plasmid pWF36 was constructed by ligating a BglII-PstI fragment from +840 to +1300 of the CYH2 gene (from plasmid YEpCYH-U1, provided by H. Fried, University of North Carolina, Chapel Hill) into pGEM3Z. Plasmids were grown in Escherichia coli strain JM109, and DNA was extracted as described (Sambrook et al. 1989). Restriction digests were performed as recommended by the suppliers (Promega, New England Biolabs).

\section{RNA isolation, Northern blot analysis, and RNase $H$ ablation}

Cultures (generally 5 or $15 \mathrm{ml}$ ) were grown to an $\mathrm{OD}_{600}$ of 1 in YPD at room temperature and were shifted to a $37^{\circ} \mathrm{C}$ water bath for the indicated length of time, then cooled in ice water prior to RNA extraction. For cultures shifted $10 \mathrm{~min}$ or less, $5-\mathrm{ml}$ cultures were grown to an $\mathrm{OD}_{600}$ of 1 and quickly mixed with an equal volume of $Y P D$ prewarmed to $51^{\circ} \mathrm{C}$ and incubated at $37^{\circ} \mathrm{C}$. Cultures were poured over crushed ice. Cells were harvested by centrifugation and RNA extracted using the glass bead lysis method (Ausubel et al. 1987).

For Northern blot analysis, total RNA $(10 \mu \mathrm{g}$ ) was fractionated on $2 \%$ agarose-formaldehyde gels (Sambrook et al. 1989) and transferred to ZetaProbe nylon membrane (Bio-Rad) with $10 \times$ SSC. Gene-specific RNA probes were synthesized using T7 (pWF1 and pWF6) and SP6 (pWF36 and pWF38) viral RNA polymerases (New England Biolabs, Promega) according to the suppliers' protocols. Prehybridization was in $50 \%$ formamide (vol/ vol), $1 \times$ SSPE, $1 \%$ SDS, $0.5 \%$ Carnation nonfat dry milk, 0.5 $\mu \mathrm{g} / \mathrm{ml}$ of denatured salmon sperm DNA at $65^{\circ} \mathrm{C}$ as recommended by the supplier (Bio-Rad). Dextran sulfate to $5 \%$ (wt/ vol) and $10^{6} \mathrm{cpm} / \mathrm{ml}$ of RNA probe were added for $12-16 \mathrm{hr}$ at $65^{\circ} \mathrm{C}$. Filters were washed twice in $2 \times$ SSC, $0.1 \%$ SDS, and once in $0.2 \times \mathrm{SSC}, 0.1 \% \mathrm{SDS}$, at $65^{\circ} \mathrm{C}$ and exposed to Kodak XAR5 film.

For measurement of poly(A) tail length, oligo anti-CYH2 (5'TCTACCCTTACCCAAGATCTTACC- $3^{\prime}$ ), complementary to position +837-+861 was mixed with duplicate RNA samples and oligo $(\mathrm{dT})_{12-18}$ was added to one of each of these samples. RNase H cleavage was carried out as described /Vournakis et al. 1975). The resulting fragments were analyzed by Northern blot as described above except that $4 \%$ NuSeive agarose was used. The probe was generated as an SP6 runoff from plasmid pWF36, linearized with EcoRI.

\section{Mapping $5^{\prime}$ and $3^{\prime}$ termini}

The $5^{\prime}$ ends of CUP 1 transcripts were mapped by primer extension. Ten nanograms of $5^{\prime}$-end-labeled anti-CUP1 primer $15^{\prime}$ TCATTTCCCAGAGCAGCATG-3'), complementary to position +166 to +186 was incubated with $5 \mu \mathrm{g}$ of total RNA from yeast in $7.5 \mu \mathrm{l}$ at $42^{\circ} \mathrm{C}$ for $60 \mathrm{~min}$. Fresh extension $\mathrm{mix}(0.5 \mathrm{~mm}$ each deoxyribonucleotide, $40 \mathrm{mM} \mathrm{MgCl}_{2}, 4 \mathrm{~mm}$ dithiothreitol, $2.5 \mathrm{mg} / \mathrm{ml}$ of actinomycin $\mathrm{D}$, and 6 units of AMV reverse transcriptase) was added and tubes were incubated $30 \mathrm{~min}$ at $37^{\circ} \mathrm{C}$. Reactions were stopped by the addition of $8 \mu$ l of sequencing gel loading mix; samples were boiled for $2 \mathrm{~min}$, and half was loaded on a $6 \%$ polyacrylamide sequencing gel.

$3^{\prime}$ Termini were mapped by RNase protection, essentially as described (Sambrook et al. 1989). A 220-nucleotide probe complementary to +325 to +532 was generated by transcription of DdeI-cut plasmid pWF1 using T7 RNA polymerase. Total yeast RNA $(20 \mu \mathrm{g}$ ) was incubated in $30 \mu$ l of $40 \mathrm{~mm}$ PIPES (pH 6.4), 1 mM EDTA, $0.4 \mathrm{M} \mathrm{NaCl}, 80 \%$ formamide with $1.5 \times 10^{5} \mathrm{cpm}$ probe for $10 \mathrm{~min}$ at $85^{\circ} \mathrm{C}$, followed by $16 \mathrm{hr}$ at $48^{\circ} \mathrm{C}$. Then 300 $\mu l$ of RNase mix [ $300 \mathrm{~mm} \mathrm{NaCl}, 10 \mathrm{~mm}$ Tris $(\mathrm{pH} 7.4), 5 \mathrm{~mm}$ EDTA, 0.5 units of RNase T1, $10 \mathrm{ng}$ of RNase A] was added, and samples were incubated for $60 \mathrm{~min}$ at $30^{\circ} \mathrm{C}$. Twenty microliters of $10 \%$ SDS and $10 \mu \mathrm{l}$ of $10 \mathrm{mg} / \mathrm{ml}$ proteinase $\mathrm{K}$ was added, and samples were incubated for $30 \mathrm{~min}$ at $37^{\circ} \mathrm{C}$. Samples were extracted once with $50: 50$ phenol : chloroform and ethanol precipitated. Pellets were dried, resuspended in sequencing gel loading solution and analyzed by electrophoresis in $8 \%$ polyacrylamide sequencing gel.

\section{Bulk poly $(A)$ length determination}

Total RNA was treated with $2 \mathrm{mg} / \mathrm{ml}$ of bovine pancreatic ribonuclease and $1000 \mathrm{U} / \mathrm{ml}$ of RNase T1 to hydrolyze all sequences other than poly(A). RNA was labeled by incubation with $100 \mu \mathrm{Ci}$ of $5^{\prime}{ }^{32} \mathrm{P}$ cytidine $3^{\prime}, 5^{\prime}$-bis(phosphate) (NEN Dupont) in $50 \mathrm{~mm}$ Tris- $\mathrm{HCl}(\mathrm{pH} 7.9), 15 \mathrm{~mm} \mathrm{MgCl}, 3.3 \mathrm{~mm}$ dithiothreitol, $2 \%$ (vol/vol) dimethyl sulfoxide, $10 \mathrm{mg} / \mathrm{ml}$ of bovine serum albumin, $25 \mu \mathrm{M}$ ATP, and 10 units of T4 RNA ligase (New England Biolabs) for $21 \mathrm{hr}$ at $4^{\circ} \mathrm{C}$. RNA samples were extracted with phenol/chloroform and ethanol precipitated. Pellets were resuspended in $96 \%$ formamide, $0.1 \%$ bromophenol blue, and $0.1 \%$ xylene cyanol, boiled for $2 \mathrm{~min}$, and loaded onto a $10 \%$ polyacrylamide/7. $\mathrm{M}$ urea gel in TBE. After electrophoresis, the gel was dried and exposed to Kodak XAR5 film.

\section{Staining by in situ hybridization}

In situ hybridizations and immunofluorescence stainings were performed as described (Kadowaki et al. 1992), with several modifications. Cultures were grown to an $\mathrm{OD}_{600}$ of $0.5-1$ and heated for $30 \mathrm{~min}$ at $37^{\circ} \mathrm{C}$, where required. Cells were fixed with $4 \%$ formaldehyde for $45 \mathrm{~min}$, washed three times in solution $\mathrm{A}$ [1.2 M sorbitol, $100 \mathrm{mM} \mathrm{KPO}_{4}$ buffer (pH 7.5)], and spheroplasted for $20 \mathrm{~min}$ at $30^{\circ} \mathrm{C}$ in solution A containing $0.1 \mathrm{mg} / \mathrm{ml}$ of oxalolyticase, $30 \mathrm{~mm} \beta$-mercaptoethanol, $60 \mu \mathrm{g} / \mathrm{ml}$ of PMSF, and the protease inhibitors aprotinin, leupeptin, and pepstatin at 1 $\mu \mathrm{g} / \mathrm{ml}$. Cells were washed in solution A and spotted onto poly- 
L-lysine-coated coverslips for $30 \mathrm{~min}$ at $4^{\circ} \mathrm{C}$, washed again, and dehydrated in $70 \%$ ethanol overnight. In situ hybridization was performed overnight at $37^{\circ} \mathrm{C}$ in $20 \mu \mathrm{l}$ of a mix containing $10-20$ ng of oligo(dT) ${ }_{25-30}$ (Pharmacia), 3'-end-labeled with digoxigenin-11-dUTP (Boehringer Mannheim) and terminal transferase (BRL), $20 \mu \mathrm{g}$ of salmon sperm DNA, $20 \mu \mathrm{g}$ of tRNA, $2 \times \mathrm{SSC}$, $0.2 \% \mathrm{BSA}, 10 \mathrm{~mm}$ vanadyl ribonucleoside complexes, and $10 \%$ dextran sulfate. The coverslips were washed three times in $2 \times$ $\mathrm{SSC}$ at $37^{\circ} \mathrm{C}$ and three times in $1 \times \mathrm{SSC}$ at room temperature $(10$ min per wash); they were treated for 5 min with buffer B [150 $\mathrm{mM} \mathrm{NaCl}, 100 \mathrm{~mm}$ Tris $(\mathrm{pH} 7.5)]$ containing $0.1 \%$ Triton and rinsed twice with buffer $\mathrm{B}$. The coverslips were incubated for 60 min at room temperature with a sheep polyclonal anti-digoxigenin antibody conjugated with rhodamine (Boehringer Mannheim/ in buffer B containing 1\% BSA. The coverslips were washed $15 \mathrm{~min}$ in buffer $\mathrm{B}$ and $15 \mathrm{~min}$ in $300 \mathrm{~mm} \mathrm{NaCl}$, and $1 \mathrm{Co}$ $\mathrm{mM}$ Tris $\langle\mathrm{pH} \mathrm{7.5}\rangle$ and mounted on slides with one drop of $90 \%$ glycerol, containing $1 \mathrm{mg} / \mathrm{ml}$ of $p$-phenylenediamine, $100 \mathrm{ng} /$ $\mathrm{ml}$ of 4', 6-diamido-2-phenylindole (DAPI), and PBS. Pictures were taken with a Zeiss Axiophot microscope.

\section{Acknowledgments}

We thank M. Culbertson, M. Nonet, and J. Abelson for providing strains, and M. Johnston, J. Warner, and H. Fried for providing plasmids. We thank $M$. Culbertson and the members of his laboratory for invaluable technical help, and J. Ferrell and C. Walczak for helpful comments on the manuscript. We also appreciate the suggestions of M. Sheets, C. Fox, and A. Bilger and the assistance of Laura VanderPloeg and Adam Steinberg in the assembly of figures. This work was supported by National Institutes of Health (NIH) grants to M.W. (GM31892) and M.R. (GM23549), an NIH Research Career Development Award [GM00521) to M.W., a Cellular and Molecular Biology Predoctoral Training Grant to W.F., and a fellowship award from Fonds National Suisse pour la Recherche Scientifique (823A-028378) to F.S.

The publication costs of this article were defrayed in part by payment of page charges. This article must therefore be hereby marked "advertisement" in accordance with 18 USC section 1734 solely to indicate this fact.

\section{References}

Aebi, M., M.W. Clark, U. Vijayraghavan, and J. Abelson. 1990. A yeast mutant, PRP20, altered in mRNA metabolism and maintenance of nuclear structure, is defective in a gene homologous to the human gene $R C C 1$, which is involved in the control of chromosome condensation. Mol. Gen. Genet. 224: 72-80.

Ausubel, F.M., R. Brent, R.E. Kingston, D.D. Moore, J.G. Seidman, J.A. Smith, and K. Struhl. 1987. In Current protocols in molecular biology. Greene/Wiley, New York.

Beyer, A.L. and Y.N. Osheim. 1988. Splice site selection, rate of splicing and alternative splicing on nascent transcripts. Genes \& Dev. 2: 754-765.

Bischoff, F.R. and H. Ponstingl. 1991. Catalysis of guanine nucleotide exchange on Ran by the mitotic regulator RCC1. Nature 354: 80-82.

Butt, T.R., E.J. Sternberg, J.A. Gorman, P. Clark, D. Hamer, M. Rosenberg, and S.T. Crooke. 1984. Copper metallothionein of yeast, structure of the gene, and regulation of expression. Proc. Nat1. Acad. Sci. 81: 3332-3336.

Clark, K.L. and G.F. Sprague, Jr. 1989. Yeast pheromone response pathway: Characterization of a suppressor that re- stores mating to receptorless mutants. Mol. Cell. Biol. 9: 2682-2694.

Clark, K.L., M. Ohtsubo, T. Nishimoto, M. Goebl, and G.F. Sprague, Jr. 1991. The yeast SRM1 protein and human $R C C 1$ protein share analogous functions. Cell Regul. 2: 781-792.

Connelly, S. and J.L. Manley. 1988. A functional mRNA polyadenylation signal is required for transcription termination by RNA polymerase II. Genes \& Dev. 2: 440-452.

Eckner, R., W. Ellmeier, and M.L. Birnstiel. 1991. Mature mRNA $3^{\prime}$ end formation stimulates RNA export from the nucleus. $E M B O$ I. 10: 3513-3522.

Fleischmann, M., M.W. Clark, W. Forrester, M. Wickens, T. Nishimoto, and M. Aebi. 1991. Analysis of yeast prp20 mutations and functional complementation by the human homologue $\mathrm{RCCl}$, a protein involved in the control of chromosome condensation. Mol. Gen. Genet, 227: 417-423.

Frasch, M. 1991. The maternally expressed Drosophila gene encoding the chromatin-binding protein $\mathrm{BJ} 1$ is a homolog of the vertebrate gene regulator of chromatin condensation, $R C C 1$. EMBO I. 10: 1225-1236.

Green, M. 1991. Biochemical mechanisms of constitutive and regulated pre-mRNA splicing. Annu. Rev. Cell Biol. 7: 559599.

Groner, B., N. Hynes, and S. Phillips. 1974. Length heterogeneity in the poly(adenylic acid) region of yeast messenger ribonucleic acid. Biochemistry 13: 5378-5382.

Guthrie, C. 1991. Messenger RNA splicing in yeast: Clues to why the spliceosome is a ribonucleoprotein. Science 253: $157-163$.

Hartwell, L.H. 1967. Macromolecule synthesis in temperaturesensitive mutants of yeast. J. Bacteriol. 93: 1662-1670.

Herrick, D., R. Parker, and A. Jacobson. 1990. Identification and comparison of stable and unstable mRNAs in Saccharomyces cerevisiae. Mol. Cell. Biol. 10: 2269-2284.

Hopper, A.K., F. Banks, and V. Evangelidis. 1978. A yeast mutant which accumulates precursor tRNAs. Cell 14: 211-219.

Hopper, A.K., H.M. Traglia, and R.W. Dunst. 1990. The yeast RNA1 gene product necessary for RNA processing is located in the cytosol and apparently excluded from the nucleus. $I$. Cell. Biol. 111: 309-321.

Hutchison, H.T., L.H. Hartwell, and C.S. McLaughlin. 1969. Temperature-sensitive yeast mutant defective in ribonucleic acid production. J. Bacteriol. 99: 807-814.

Kadowaki, T., Y. Zhao, and A.M. Tartakoff. 1992. A conditional yeast mutant deficient in mRNA transport from nucleus to cytoplasm. Proc. Natl. Acad. Sci. 89: 2312-2316.

Karin, M., R. Najarian, A. Haslinger, P. Valenzuela, J. Welch, and S. Fogel. 1984. Primary structure and transcription of an amplified genetic locus: The CUP1 locus of yeast. Proc. Natl. Acad. Sci. 81: 337-341.

Kaufer, N.F., H.M. Fried, W.F. Schwindinger, M. Jasin, and J.R. Warner. 1983. Cycloheximide resistance in yeast: the gene and its protein. Nucleic Acids Res. 11: 3123-3135.

Knapp, G., J.S. Beckmann, P.F. Johnson, S.A. Fuhrman, and J. Abelson. 1978. Transcription and processing of intervening sequences in yeast tRNA genes. Cell 14: 221-236.

LeMaire, M.F. and C.S. Thummel. 1990. Splicing precedes polyadenylation during Drosophila E74A transcription. Mol. Cell. Biol. 10: 6059-6063.

Lingner, J., J. Kellermann, and W. Keller. 1991. Cloning and expression of the essential gene for poly(A) polymerase from S. cerevisiae. Nature 354: 496-498.

Logan, J., E. Falck-Pederson, J.E. Darnell, Jr., and T. Shenk. 1987. A poly(A) addition site and a downstream termination region are required for efficient cessation of transcription by RNA polymerase II in the mouse beta major-globin gene. Proc. 
Natl. Acad. Sci. 84: 8306-8310.

Matsumoto, T. and D. Beach. 1991. Premature initiation of mitosis in yeast lacking $\mathrm{RCCl}$ or an interacting GTPase. Cell 66: 347-360.

Nevins, J.R. and J.E. Darnell, Jr. 1978. Steps in the processing of Ad2 mRNA: Poly $(A)^{+}$nuclear sequences are conserved and poly(A) addition precedes splicing. Cell 15: 1477-1493.

Nishitani, H., H. Kobayashi, M. Ohtsubo, and T. Nishimoto. 1990. Cloning of Xenopus RCCl cDNA, a homolog of the human RCCl gene: Complementation of tsBN2 mutation and identification of the product. $/$. Biochem. 107: 228-235.

Nishitani, H., M. Ohtsubo, K. Yamashita, H. Iida, J. Pines, H. Yasudo, Y. Shibata, T. Hunter, and T. Nishimoto. 1991. Loss of $\mathrm{RCCl}$, a nuclear DNA-binding protein, uncouples the completion of DNA replication from the activation of $\mathrm{CDC} 2$ protein kinase and mitosis. EMBO J. 10: 1555-1564.

Nonet, M., C. Scafe, J. Sexton, and R. Young. 1987. Eucaryotic RNA polymerase conditional mutant that rapidly ceases mRNA synthesis. Mol. Cell. Biol. 7: 1602-1611.

Ohtsubo, M., R. Kai, N. Furuno, T. Sekiguchi, M. Sekiguch), H. Hayashida, K. Kuma, T. Miyata, S. Fukushige, T. Murotsu, K. Matsubara, and T. Nishimoto. 1987. Isolation and characterization of the active cDNA of the human cell cycle gene ( $\mathrm{RCCl}$ ) involved in the regulation of onset of chromosome condensation. Genes \& Dev. 1: 585-593.

Ohtsubo, M., H. Okazaki, and T. Nishimoto. 1989. The RCCl protein, a regulator for the onset of chromosome condensation, locates in the nucleus and binds to DNA. I. Cell Biol. 109: 1389-1397.

Ohtsubo, M., T. Yoshida, H. Seino, H. Nishitani, K.L. Clark, G.F. Sprague, Jr., M. Frasch, and T. Nishimoto. 1991. Mutation of the hamster cell cycle gene $\mathrm{RCCl}$ is complemented by the homologous genes of Drosophila and $S$. cerevisiae. EMBO /. 10: 1265-1273.

Osborne, B.I. and L. Guarente. 1989. Mutational analysis of a yeast transcriptional terminator. Proc. Natl. Acad. Sci. 86: 4097-4101.

Piper, P.W. and J.L. Aamand. 1989. Yeast mutation thought to arrest mRNA transport markedly increases the length of the 3' poly(A) on polyadenylated RNA. J. Mol. Biol. 208: 697700.

Raabe, T., F.J. Bollum, and J.L. Manley. 1991. Primary structure and expression of bovine poly(A) polymerase. Nature 353: 229-234.

St. John, T.P. and R.W. Davis. 1981. The organization and transcription of the galactose gene cluster of Saccharomyces. $I$. Mol. Biol. 152: 285-315.

Sambrook, J., E.F. Fritsch, and T. Maniatis. 1989. Molecular cloning: A laboratory manual. Cold Spring Harbor Laboratory Press, Cold Spring Harbor, New York.

Sherman, F. 1991. Guide to yeast genetics and molecular biology (ed. C. Guthrie and G.R. Fink), vol. 194, pp. 3-21. Academic Press, San Diego, CA.

Shiokawa, K. and A.O. Pogo. 1974. The role of cytoplasmic membranes in controlling the transport of nuclear messenger RNA and initiation of protein synthesis. Proc. Natl. Acad. Sci. 71: 2658-2662.

Uchida, S., T. Sekiguchi, H. Nishitani, K. Miyauchi, M. Ohtsubo, and T. Nishimoto. 1990. Premature chromosome condensation is induced by a point mutation in the hamster RCCl gene. Mol. Cell. Biol. 10: 577-584.

Vijayraghavan, U., M. Company, and J. Abelson. 1989. Isolation and characterization of pre-mRNA splicing mutants of Saccharomyces cerevisiae. Genes \& Dev. 3: 1206-1216.

Vournakis, J.N., A. Efstratiadis, and F.C. Kafatos. 1975. Electrophoretic patterns of deadenylylated chorion and globin $\mathrm{mR}$ -
NAs. Proc. Natl. Acad. Sci. 72: 2959-2963.

Wickens, M. 1990 . How the messenger got its tail: Addition of poly(A) in the nucleus. Trends Biochem. Sci. 15: 277-281.

Winey, M. and M.R. Culbertson. 1988. Mutations affecting the tRNA-splicing endonuclease activity of Saccharomyces cerevisiae. Genetics 118: 609-617. 


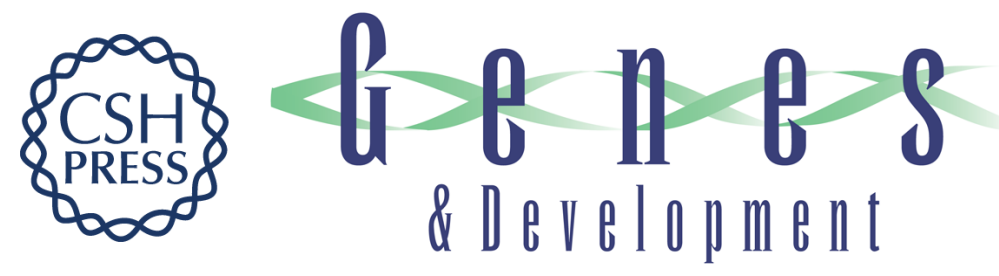

\section{Defects in mRNA 3'-end formation, transcription initiation, and mRNA transport associated with the yeast mutation prp20: possible coupling of mRNA processing and chromatin structure.}

W Forrester, F Stutz, M Rosbash, et al.

Genes Dev. 1992, 6:

Access the most recent version at doi:10.1101/gad.6.10.1914

References This article cites 43 articles, 22 of which can be accessed free at:

http://genesdev.cshlp.org/content/6/10/1914.full.html\#ref-list-1

License

Email Alerting

Service

Receive free email alerts when new articles cite this article - sign up in the box at the top right corner of the article or click here.

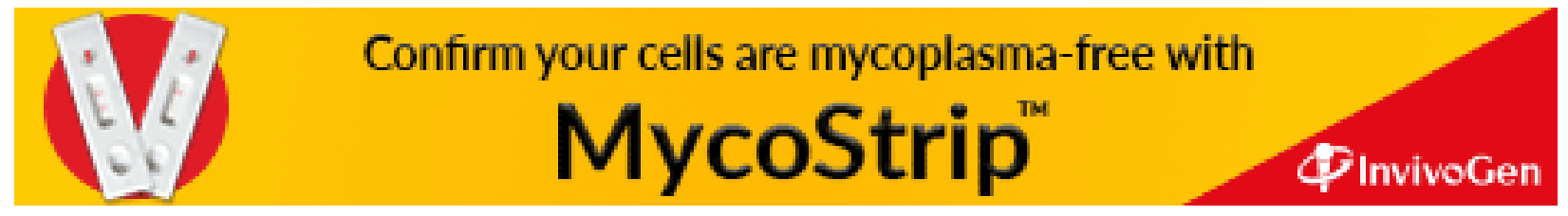

